\title{
Second Annual Conference of the Center for the Study of Islam \& Democracy (CSID)
}

The Center for the Study of Islam and Democracy (CSID) held its second annual conference at Georgetown University on April 7, 2001. Students, diplomats, liberal professionals, investors, activists and academicians were among the guests at the conference cosponsored by Georgetown University's Center for Muslim Christian Understanding (CMCU), the International Institute of Islamic Thought (IIIT), and the Institute of Global Cultural Studies.

The conference theme, "Islam, Democracy and the Secularist State in the Post Modern Era" echoed in the presentations of Muslim scholars in the following five panels: Islam and Democracy, The Secular State, Elements of Democracy with Respect to Islam, Postmodernity, and Democracy in Practice and Islam in Context. A total of twenty presentations were made by the panelists in these five sections.

Since the CSID is a research organization with a membership of academics, entrepreneurs, Muslim intellectuals, liberal professionals and activists committed to promoting democracy in the Muslim world, its annual conferences and monthly publication "The Muslim Democrat" serve as a forum through which the relationship between Islam and democracy is defined and democratic elements inherent in Islam are identified. As a think-tank dedicated to defining the historical and philosophical basis of democracy and its compatibility with the elements of Islam, CSID's presentations underscored justice, equality and tolerance as democratic concepts intrinsic to Islamic principles.

By outlining the historical development of secularism and its role in Muslim societies, the panelists did not only encourage Muslim activists to institutionalize democratic practices, but they also addressed Muslim scholars and activists from both the western and the Muslim worlds who are convinced that Islam is incompatible with democracy. By presenting the causes of problems inherent in secular trends in Muslim countries like Yemen, Jordan, Indonesia and Malaysia, and identifying the shortcomings in their democratization process, CSID's presentations simultaneously sought to convince both Islamists and secularists that democratic ideals and Islamic principles were compatible.

Since a distinction must be made between the separation of church and state and the separation of religion from politics in order to advance the 
historical dialogue between Islam and democracy, this annual conference can be remembered as playing an important role in advancing the historical dialogue between Islam, democracy and secularism.

In his concluding remarks, Dr. Ali Mazrui outlined four types of states - the secular state like the USA; the state with an established religion like the Islamic Republic of Iran or England; the atheistic state like the former Soviet Union and China; and the ecumenical state like Lebanon. Mazrui concluded that since the separation of church from state is institutional, and the separation of religion from politics is behavioral, it is usually easier to cope with problems based on institutional arrangements than with those based on behavioral elements. The distinction, however, between these two concepts was implicit in CSID's presentations due to its efforts to study these elements and their impact on the relationship between Islam and democracy.

In fact, an examination of this distinction is crucial for understanding the four different types of states and developing the historical dialogue between Islam and democracy, and pivotal in defining the sociopolitical issues that confront Muslim countries operating in secular societies like Turkey and India and more ambivalent societies like Egypt, Lebanon, Jordan, Indonesia and Malaysia.

The historical dialogue between Islam and democracy was clearly defined in Dr. Louay Safi's presentation, "Islam and the Secular State." In the following statement, Safi clarified the distinction between these two concepts by pointing to the reason behind the separation of church and state and identifying the need to analyze the role that religion plays in the democratization process operating in secular societies. "While the secular state was designed to prevent organized religion from controlling public institutions, it did not aim at undermining religiosity per se, ... it was perceived as multireligious society's best defense against the imposition of the religious values and worldview of one's community on another." He stressed, however, that secularization gradually undermines the role of morality in public life to the extent that a fresh look at the role of morality and religion in guiding public policy is urgently needed.

Other presentations stimulated further debate and sometimes controversy. For example, the presentation in the third panel, "The Search for a Third Discourse: Beyond Tradition and Ideology", by M. A. Muqtedar Khan, examined the ideas of Abdul Kareem Soroush, Muhammad Khatami, Farid Esack and Maulana Waheeduddin in hopes of identifying a 
new approach through which Islam would be seen as democracy's partner. In the presentation by Fred R. Dallmayr, "Reflections on Abdel Karim Soroush," "religious government" or the role of religion in politics emerged as the key to democratic government. In the fourth panel, Dr. Mohammad Moniruzzaman defined Islam as "The Underlying Principle " of a democracy, because Islam is a system that addresses human concerns more often than metaphysical concepts.

In his Luncheon Keynote Address, Abdolkarim Soroush contended that there is "no separation between church and state because religion and democracy are two parts of a whole." He further identified the ethical role that religion plays in politics, arguing that a "system of Islamic philosophy can be independent of religion and Islam, and can work compatibly with the Islamic world at large."

The most important element missing in the five panels was the discussion of domestic issues prevalent in the immediate world closely associated with secular America, and not just the wider world, i.e., Muslim countries. Since part of democracy is to dialogue on controversial issues, addressing divisive, contentious issues in American society is important for the development of the historical dialogue between Islam and democracy. It is only by identifying Islamic and secular positions on such issues as the role of prayer in schools, affirmative action and abortion that the relationship between Islam and democracy in America can be fully defined.

Furthermore, if institutions in democratic Muslim countries are developed according to western models, then the western model of democracy serves as the scale against which the compatibility of Islam with democracy in secular societies is measured. It is important to dialogue on controversial issues and not avoid or deny them, if we are to produce an accurate picture of how secularism and democracy affect the quality of life within the US and in the larger world society.

Layla Sein Assistant Editor, AJISS AMSS Coordinator 